\title{
Procalcitonin and C-reactive protein in urinary tract infection diagnosis
}

\author{
Rui-Ying $\mathrm{Xu}^{*}$, Hua-Wei Liu, Ji-Ling Liu and Jun-Hua Dong
}

\begin{abstract}
Background: Urinary infections are a common type of pediatric disease, and their treatment and prognosis are closely correlated with infection location. Common clinical manifestations and laboratory tests are insufficient to differentiate between acute pyelonephritis and lower urinary tract infection. This study was conducted to explore a diagnostic method for upper and lower urinary tract infection differentiation.

Methods: The diagnostic values of procalcitonin (PCT) and C-reactive protein (CRP) were analyzed using the receiver operating characteristic curve method for upper and lower urinary tract infection differentiation. PCT was determined using chemiluminescent immunoassay.

Results: The PCT and CRP values in children with acute pyelonephritis were significantly higher than those in children with lower urinary tract infection $(3.90 \pm 3.51 \mathrm{ng} / \mathrm{ml}$ and $68.17 \pm 39.42 \mathrm{mg} / \mathrm{l} \mathrm{vs} .0 .48 \pm 0.39 \mathrm{ng} / \mathrm{ml}$ and 21.39 $\pm 14.92 \mathrm{mg} / \mathrm{l})$. The PCT values were correlated with the degree of renal involvement, whereas the CRP values failed to show such a significant correlation. PCT had a sensitivity of $90.47 \%$ and a specificity of $88 \%$ in predicting nephropathia, whereas CRP had sensitivity of $85.71 \%$ and a specificity of $48 \%$.

Conclusions: Both PCT and CRP can be used for upper and lower urinary tract infection differentiation, but PCT has higher sensitivity and specificity in predicting pyelonephritis than CRP. PCT showed better results than CRP. PCT values were also correlated with the degree of renal involvement.
\end{abstract}

Keywords: Urinary tract infections, Acute pyelonephritis, Receiver operating characteristic curve, Procalcitonin

\section{Background}

Urinary infections are a common pediatric disease and their treatment and prognosis are closely correlated with infection location. Common clinical manifestations and laboratory indices are insufficient for acute pyelonephritis and lower urinary tract infection (UTI) differentiation. Differentiating between these diseases is particularly difficult for infants and children, but is necessary because pyelonephritis poses a risk of renal parenchyma involvement, which can lead to renal scar formation, as well as high blood pressure and end stage renal failure in adults [1-4]. Smellie et al. conducted a retrospective analysis of 52 patients with neodevelopment or progressive renal scars and revealed that 50 of these patients had a medical history of urinary infection diagnosis or treatment delay [5]. Therefore, finding a

\footnotetext{
* Correspondence: zjqqcn@126.com

Department of Pediatrics, Qilu Hospital of Shan Dong University, Jinan 250012, China
}

technically easy and practical method for differentiating between upper and lower UTIs is urgently required.

As of this writing, ${ }^{99 \mathrm{~m}} \mathrm{Tc}$-dimercaptosuccinic acid (DMSA) scintigraphy is a commonly adopted method for diagnosing severity degrees of renal involvement and pyelonephritis. However, this method is costly and is radioactive to sick children [6,7]. Procalcitonin (PCT) is a type of hormonal activity-free calcitonin precursor protein that can serve as an early diagnosis index of serious bacterial infections and septicemia; PCT is also correlated with the severity of bacterial infections [8-10]. PCT is a satisfactory predictor of renal parenchymal involvement in acute and late renal scars [11-13].

We retrospectively analyzed the diagnostic value of PCT in differentiating upper and lower UTIs, and the serum PCT level was determined and compared with C-reactive protein (CRP) and peripheral blood leukocyte count; the results were subsequently analyzed using the receiver operating characteristic (ROC) method $[14,15]$. 


\section{Methods}

\section{Clinical data}

A total of 46 patients with suspected acute pyelonephritis (APN) were enrolled in the study from December 1999 to April 2002. Twenty-eight females and 18 males were included, and their ages ranged from 2 months old to 14 years old. Inclusion criteria were as follows: fever $\left(\geq 38.5^{\circ} \mathrm{C}\right.$, axillary), pyuria ( $\geq 10$ white blood cells per high-power field on a spun urine), and positive urine culture $(\geq 100,000$ colonies/ml of a single organism, clean catch). Exclusion criteria included the presence of renal calculi, obstructive uropathy, and a neurogenic bladder.

We performed a retrospective analysis of 46 admitted patients, who underwent a DMSA renal scan for suspected APN within $5 \mathrm{~d}$ of admission.

APN was confirmed using radioactive nuclide ${ }^{99 m}$ TcDMSA scanning. Diagnostic criteria were based on literature [16]. APN is indicated when radioactive renal parenchyma distributional sparse or loss areas are present and accompanied with swelling or a normal kidney profile. Renal scar formation is diagnosed when the kidney volume decreases (manifested by cortex attenuation, renal morphologic abnormality, or profile shrinkage) with wedge-shaped defects. Renal involvement was graded as follows: renal injury $<25 \%$ was considered mild; renal injury between $25 \%$ and $50 \%$ was considered moderate; and renal injury $>50 \%$ was considered serious. Lower UTI was diagnosed by normal DMSA scanning. If the first DMSA findings were abnormal, another analysis was performed six months later. All patients underwent renal ultrasonography within $48 \mathrm{~h}$ of admission, and eight recurrent patients underwent voiding cystourethrography within $7 \mathrm{~d}$ of admission.

\section{Experimental methods}

The patients were divided into APN and lower UTI groups and treated as follows: two weeks of antibiotic treatment for APN patients, $7 \mathrm{~d}$ of antibiotic treatment for Lower UTI. PCT was determined using chemiluminescent immunoassay, and CRP was scored using nephrometry scoring. PCT, CRP, and white blood cell (WBC) count were determined within $24 \mathrm{~h}$ of admission and $24 \mathrm{~h}$ of therapy.

\section{Statistical analysis}

All data were normally distributed and were presented as mean \pm standard error $(\bar{x} \pm \mathrm{s})$. T-tests were performed to compare the means between groups. Cut points were selected and then graded according to normal, basically normal, susceptible, basically abnormal, and abnormal classifications. Se and Sp of each point were calculated. Taking Se as the ordinate, which represented true positive rate, and (1-Sp) as the abscissa, which represented false positive rate. ROC curves were drawn by the SPSS 10.0 software to calculate the area under curve and standard errors. The cut-off value was selected
Table 1 Comparisons of the laboratory outcomes between groups $(\bar{x} \pm \mathrm{s})$

\begin{tabular}{|c|c|c|c|}
\hline Group & $\begin{array}{c}\text { PCT } \\
\left(\rho / \mathrm{ng} \mathrm{ml}^{-1}\right)\end{array}$ & $\begin{array}{c}\text { CRP } \\
\left(\rho / \mathrm{mg}^{\left.-l^{-1}\right)}\right.\end{array}$ & $\begin{array}{c}\text { WBC number } \\
\left(/ \mathrm{mm}^{3}\right)\end{array}$ \\
\hline Lower urine tract infection & $0.48 \pm 0.39$ & $21.39 \pm 14.92$ & $14068 \pm 6870$ \\
\hline Acute pyelonephritis & $3.90 \pm 3.51$ & $68.17 \pm 39.42$ & $15882 \pm 7350$ \\
\hline$p$ value & $<0.01$ & $<0.01$ & $>0.05$ \\
\hline
\end{tabular}

depending on $(\mathrm{Sp}+\mathrm{Se})_{\max }$. Values of different indices were also compared.

This study was conducted in accordance with the declaration of Helsinki and with approval from the Ethics Committee of Qilu Hospital of Shan Dong University. Written informed consent was obtained from all parent or guardian of participants.

\section{Results}

\section{Clinical data}

A total of 46 children with urinary infection who received treatment between December 1999 and April 2002 were enrolled. Among the patients, 18 were males and 28 were females. Their ages ranged from 2 months old to 14 years old: six males and two females were $<1$ year old, seven males and 11 females were between 1 year old and 3 years old, and five males and 15 females were $\geq 3$ years old. A total of 38 patients had primary urinary infection, and eight had recurrent infection. Their courses of disease ranged from $3 \mathrm{~d}$ to $1 \mathrm{yr}$. These patients did not receive antibiotic treatment within half a month before hospitalization. A total of 40 patients had body temperatures between $38.5^{\circ} \mathrm{C}$ and $40.0^{\circ} \mathrm{C}$. Twentyeight patients presented UTI symptoms, such as frequent micturition, urgent micturition, odynuria, and crying while urinating. Twelve patients had lumbago and percussion pain

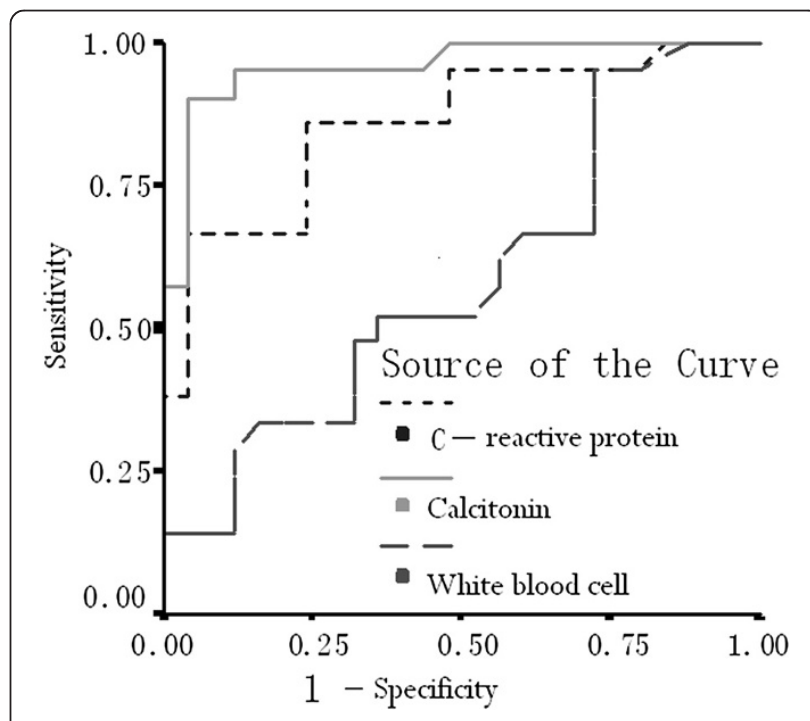

Figure 1 Comparison of the ROC curves of PCT, CRP and WBC. 
Table 2 Comparisons of the diagnostic values of PCR, CRP, and WBC for acute pyelonephritis (\%)

\begin{tabular}{lcccccc}
\hline Index & Diagnostic reference value & Sensitivity & Specificity & Accuracy & Positive predictive value & Negative predictive value \\
\hline PCT & $1 \mathrm{ng} / \mathrm{ml}$ & 90.47 & 88 & 89 & 87 & 95 \\
$\mathrm{CRP}$ & $20 \mathrm{mg} / \mathrm{l}$ & 85.71 & 48 & 86.9 & 58 & 80 \\
WBC & $15000 / \mathrm{mm}^{3}$ & 57 & 44 & 71 & 46 & 55 \\
\hline
\end{tabular}

on kidney region. Four patients had macroscopic hematuria. Eight patients, six of whom were less than 2 years old, presented non-specific signs and symptoms, such as emesis, diarrhea, abdominal pain, poor disposition and appetite, icterus, and irritability. All patients had WBC count $>10 / \mathrm{HP}$, 12 had red blood cell count of $>5 / \mathrm{HP}$, and 11 had urine protein between + and ++ , according to routine urine examination. Urine culture outcomes of all patients were positive.

\section{Radioactive nuclide scanning}

Twenty-one out of the 46 patients were diagnosed with APN. Among these patients, two had non-obstructive hydronephrosis, one presented renal scar formation, and two presented vesico-ureteral reflux.

\section{PCT and CRP}

The serum PCT and CRP levels of the APN group were significantly higher than those of the lower UTI group $(3.90 \pm 3.51 \mathrm{ng} / \mathrm{ml}$ and $68.17 \pm 39.42 \mathrm{mg} / \mathrm{l}$ vs. $0.48 \pm$ $0.39 \mathrm{ng} / \mathrm{ml}$ and $21.39 \pm 14.92 \mathrm{mg} / \mathrm{l}, P<0.01$, Table 1$)$. Correlation analysis demonstrated that PCT and CRP were in a significantly positive correlation with a correlation coefficient of $0.729(P<0.01)$.

\section{Curve analysis}

As shown in Figure 1, the areas under the PCT, CRP, and WBC curves were $0.958,0.858$, and 0.588 , respectively. Group comparison analysis showed no significant difference between the areas under the PCT and CRP curves $(P>0.05)$, whereas the areas under these curves were significantly larger than that under the WBC curve $(P<0.01)$. $\mathrm{PCT}$ and CRP are highly accurate in diagnosing APN.

\section{Diagnostic values}

The diagnostic values of PCT, CRP, and WBC were $1.0 \mathrm{ng} / \mathrm{ml}, 20 \mathrm{mg} / \mathrm{l}$, and $15,000 / \mathrm{mm}^{3}$, respectively. The sensitivity and specificity of PCT in predicting nephropathia were $90.47 \%$ and $88 \%$, whereas those of CRP were $85.71 \%$ and $48 \%$, respectively. PCT had the highest sensitivity and specificity in diagnosing APN among the three methods. The results are summarized in Table 2.

\section{Renal involvement degrees}

The PCT level in children with serious renal involvement $(8.60 \pm 2.80 \mathrm{ng} / \mathrm{ml})$ was noticeably higher than that in children with mild and moderate renal involvement $(2.02 \pm$ $1.24 \mathrm{ng} / \mathrm{ml} ; P<0.01)$, whereas the WBC counts and serum
CRP levels among children with different renal involvement degrees did not show significant differences $(P>$ 0.05). High PCT value indicates a serious degree of renal involvement. The results are summarized in Table 3.

\section{PCT and CRP outcome analysis}

The pre- and post-treatment PCT levels were $3.90 \pm 3.51$ and $1.78 \pm 2.07 \mathrm{ng} / \mathrm{ml}$, respectively, and the pre- and posttreatment CRP levels were $68.17 \pm 39.42$ and $26.13 \pm$ $15.14 \mathrm{mg} / \mathrm{l}$. Great differences in the PCT and CRP were observed before and after treatment $(P<0.05)$. Follow-up DMSA scanning at six months after treatment showed that 15 children completely recovered, three showed great improvement, two showed little improvement, and one failed to show noticeable improvement. The child who failed to show noticeable improvement had renal scars with vesico-ureteral reflux before the hospitalization, whereas all other patients had no new scars. The serum PCT levels $(>10 \mathrm{ng} / \mathrm{ml})$ in three patients before treatment were still higher than $5 \mathrm{ng} / \mathrm{ml}$ after treatment.

\section{Discussion and conclusion}

Urinary infections are a common type of pediatric disease, and their treatment and prognosis are closely associated with infection position. Differentiating APN from lower UTI is difficult based on common clinical manifestations and laboratory indices, and thus, an easier and more practical method is necessary. ${ }^{99 m}$ Tc-DMSA scintigraphy is currently a commonly adopted method for the diagnosis of renal involvement degree and pyelonephritis; this method is costly and radioactive to children [6,7].

PCT is a hormonal activity-free calcitonin precursor protein [17]. Studies have proven that PCT serves as an early diagnosis index for bacterial infections and septicemia, and that PCT is also correlated with the severity of bacterial infections; thus, PCT can predict prognosis [18-20]. Normally, PCT does not increase when local

Table 3 Comparisons between laboratory outcomes and renal involvement degrees

\begin{tabular}{lccc}
\hline Index & $\begin{array}{c}\text { Mild and moderate } \\
\text { degrees }(\mathbf{n}=15 ; \\
\text { DMSA scanning) }\end{array}$ & $\begin{array}{c}\text { Serious degree } \\
\text { ( } \mathbf{n = 6 ;} \text { DMSA } \\
\text { scanning) }\end{array}$ & $\boldsymbol{p}$ values \\
\hline $\mathrm{PCT}\left(\rho / \mathrm{ng} \cdot \mathrm{ml}^{-1}\right)$ & $2.02 \pm 1.24$ & $8.60 \pm 2.80$ & $<0.01$ \\
$\mathrm{CRP}\left(\rho / \mathrm{mg} \cdot \mathrm{l}^{-1}\right)$ & $62.0 \pm 42.83$ & $82.02 \pm 28.56$ & $>0.05$ \\
WBC $\left(\mathrm{cell} / \mathrm{s} / \mathrm{mm}^{3}\right)$ & $14990 \pm 2611$ & $15980 \pm 3220$ & $>0.05$ \\
\hline
\end{tabular}


bacterial infection occurs unless the infection is accompanied by systemic inflammatory reactions [20-22]. Most authors conclude that PCT has satisfactory diagnostic accuracy and an interesting clinical value for APN, with a sensitivity and a specificity ranging from $70 \%$ to $100 \%$ and $70 \%$ to $97 \%$, respectively, across studies and thresholds [23-28]. However, a Belgium team found lower sensitivity and specificity $(68 \%$ and $23 \%$, respectively) with no obvious difference regarding the cutoff of the characteristics of the population [29]. The average PCT and CRP levels of children with APN were greatly higher than those of children with lower UTI $(P<0.01)$. In contrast, peripheral blood WBC counts were not significant in predicting renal involvement.

The areas under the PCT, CRP, and WBC curves were $0.958,0.858$, and 0.588 , respectively, and the group analysis shows that the areas under both PCT and CRP curves displayed significant differences compared with those under the WBC curve. Both PCT and CRP can serve as laboratory indices for APN diagnosis, but PCT has a higher diagnostic value than CRP. The ROC curves in this study illustrate the same findings.

This study shows that PCR and CRP have a significant correlation with a Pearson's correlation coefficient of 0.729 $(P<0.01)$. CRP also has a diagnostic value for APN diagnosis, but its sensitivity, specificity, and accuracy are low. The sensitivity and specificity of CRP, PCT, and WBC are related to a real positive patient's threshold determination. Based on the results in this study, $1 \mathrm{ng} / \mathrm{ml}$ PCT can be considered the reference value because PCT has sensitivity of $90.47 \%$, specificity of $88 \%$, accuracy of $89 \%$, a positive predictive value of $87 \%$, and a negative predictive value of $95 \%$ in predicting APN.

The PCT and CRP levels after treatment significantly decreased compared with those before treatment $(P<$ 0.05). Both PCT and CRP can be used for observing pathogenesis and curative effect. The serum PCT value in children with serious renal involvement was significantly higher than in those with mild and moderate renal involvement. A high PCT value indicates serious renal involvement. Therefore, PCT can be applied in predicting renal involvement. The CRP values in children with serious renal involvement were higher than those in children with mild and moderate renal involvement, but no significant difference was observed.

Serum PCT determination is an easy and cheap method for diagnosing APN, and only a small amount of blood is required. Furthermore, PCT is highly stable in serum, and the entire PCT determination process can be completed in $2 \mathrm{~h}$. PCT determination can also be used for the observing curative effect and follow-up pathogenic condition sequelae, prognostic judgment, and renal involvement degree prediction. Serum PCT determination can be used in clinical settings.
The following are the limitations of this study. First, the sample size used was small. Second, PCT was initially measured with a quantitative immunoluminometric assay, but this assay was progressively replaced by PCT-sensitive KRYPTOR. Third, validation studies, threshold analyses, and studies on various effects are required before PCT is deemed safe for daily use.

\section{Competing interests}

I declare that we have no financial competing interests.

\section{Authors' contributions}

R-YX participated in the design of the study, statistical analysis and drafting the manuscript. H-WL helped to carry out the immunoassays and data analysis. J-LL helped collecting blood samples. J-HD has given medical instruction. All authors read and approved the final manuscript.

\section{Acknowledgements}

We thank Xiang-Dong Jian who provided medical writing services and technical help.

Received: 25 May 2013 Accepted: 1 May 2014

Published: 30 May 2014

\section{References}

1. Jacobson SH, Eklöf O, Eriksson CG, Lins LE, Tidgren B, Winberg J: Development of hypertension and uraemia after pyelonephritis in childhood: 27 year follow up. BMJ 1989, 299:703-706.

2. Martinell J, Jodal U, Lidin-Janson G: Pregnancies in women with and without renal scarring after urinary infection in childhood. BMJ 1990, 300:840-844.

3. Ransley PG, Risdon RA: Reflux nephropathy: effects of antimicrobial therapy on the evolution of the early pyelonephritic scar. Kidney Int 1981, 20:733-742.

4. Sacks SH, Verrier Jones K, Roberts R, Asscher AW, Ledingham JG: Effect of symptomless bacteriuria in childhood on subsequent pregnancy. Lancet 1987, 2:991-994.

5. Smellie JM, Poulton A, Prescod NP: Retrospective study of children with renal scarring associated with reflux and urinary infect. BMJ 1994, 308:1193-1196.

6. Jakobsson B, Nolstedt L, Svensson L, Söderlundh S, Berg U: 99 m Technetium-dimercaptosuccinic acid scan in the diagnosis of acute pyelonephritis in children: relation to clinical and radiological findings. Pediatr Nephrol 1992, 6:328-334.

7. Ilyas M, Mastin ST, Richard GA: Age-related radiological imaging in children with acute pyelonephritis. Pediatr Nephrol 2002, 17:30-34.

8. Hatherill M, Tibby SM, Sykes K, Turner C, Murdoch IA: Diagnostic markers of infection: comparison of procalcitonin with $C$ reactive protein and leucocyte count. Arch Dis Child 1999, 81:417-421.

9. Tang BM, Eslick GD, Craig JC, Mclean AS: Accuracy of procalcitonin for sepsis diagnosis in critically ill patients: systematic review and metaanalysis. Lancet Infect Dis 2007, 7(3):210-7.

10. Moulin F, Raymond J, Lorrot M, Marc E, Coste J, Iniguez JL, Kalifa G, Bohuon C, Gendrel D: Procalcitonin in children admitted to hospital with community acquired pneumonia. Arch Dis Child 2001, 84:332-336.

11. Mori F, Lakhanpanul M, Verrier-Jones K: Diagnosis and management of urinary tract infection in children: summery of NICE guidance. $\mathrm{Br}$ Med J 2007, 335(7616):395-397.

12. Bressans S, Andreola B, Zucchetta P, Montini G, Burei M, Perilongo G, Da Dalt L: Procalcitonin as a predictor of renal scarring in infants and young children. Pediatr Nephrol 2009, 24(6):1199-1204.

13. Nikfar R, Khotaee G, Ataee N, Shams S: Usefulness of procalcitonin rapid test for the diagnosis of acute pyelonephritis in children in the emergency department. Pediatr Int 2010, 52(2):196-198.

14. John AS: Measuring the accuracy of diagnostic systems. Science 1988 , 240:1285-1293.

15. Zweig MH, Campbell G: Receiver operating character (ROC) curve plots: a fundamental evaluation toll in clinical medicine. Clin Chem 1993, 39:561-577. 
16. Majdm M, Rushton $\mathrm{H}$ : Renal cortical scintigraphy in the diagnosis of acute pyelonephritis. Semin Nucl Med 1992, 22:98-111.

17. Meisner M, Tschaikowsky K, Schnabel S, Schmidt J, Katalinic A, Schüttler J: Procalcitonin-influence of temperature, storage, anticoagulation and arterial or venous asservation of blood samples on procalcitonin concentrations. Eur J Clin Chem Clin Biochem 1997, 35:597-601.

18. Harbarth S, Holeckova K, Froidevaux C, Pittet D, Ricou B, Grau GE, Vadas L, Pugin J: Geneva Sepsis Network: diagnostic value of Precalcitonin, Interleukin-6, and Interlerkin-8 in critically ill patients admitted with suspected sepsis. Am J Respir Crit Care Med 2001, 164:396-402.

19. Monneret G, Pachot A, Laroche B, Picollet J, Bienvenu J: Procalcitonin and calcitonin gene-related peptide decrease LPS-induced TNF production by human circulating blood cells. Cytokine 2000, 12:762-764.

20. Whang KT, Steinwald PM, White JC, Nylen ES, Snider RH, Simon GL, Goldberg RL, Becker KL: Serum calcitonin precursors in sepsis and systemic inflammation. J Clin Endocrinol Metab 1998, 83:3296-3301.

21. Assicot M, Gendrel D, Carsin H, Raymond J, Guilbaud J, Bohuon C: High serum procalcitonin concentrations in patients with sepsis and infection. Lancet 1993, 341:515-518.

22. Oberhoffer M, Stonans I, Russwurm S, Stonane E, Vogelsang H, Junker U, Jäger $L$, Reinhart K: Procalcitonin expression in human peripheral blood mononuclear cells and its modulation by lipopolysaccharides and sepsis related cytokines in vitro. J Lab Clin Med 1999, 134:49-55.

23. Karavanaki K, Haliotis FA, Sourani M, Kariyiannis C, Hantzi E, Zachariadou L, Avlonitis S, Papassotiriou I: DMSA scintigraphy in febrile urinary tract infections could be omitted in children with low procalcitonin levels. Infect Dis Clin Pract 2007, 15(6):377-381.

24. Kotoula A, Gardikis S, Tsalkidis A, Mantadakis E, Zissimopoulos A, Kambouri K, Deftereos S, Tripsianis G, Manolas K, Chatzimichael A, Vaos G: Procalcitonin for the early prediction of renal parenchymal involvement in children with UTI: preliminary results. Int Urol Nephrol 2009, 41(2):393-399.

25. Mantadakis E, Please E, Vouloumanou EK, Karageorgopoulos DE, Chatzimichael A, Falagas ME: Serum procalcitonin for prediction of renal parenchymal involvement in children with urinary tract infections: a meta-analysis of prospective clinical studies. J Pediatr 2009, 55(6):875-881.

26. Van Nieuwkoop C, Bonten TN, Van't Wout JW, Kuijper EJ, Groeneveld GH, Becker MJ, Koster T, Wattel-Louis GH, Delfos NM, Ablij HC, Leyten EM, van Dissel JT: Procalcitonin reflects bacteremia and bacterial load in urosepsis syndrome : a prospective observational study. Crit Care 2010, 14(6):R206.

27. Shen JN, Chang HM, Chen SM, Hung TW, Lue KH: The role of procalcitonin for acute pyelonephritis and subsequent renal scarring in infants and young children. J Urol 2011, 186(5):2002-8.

28. Leroy S, Fernandez-Lopez A, Nikfar R, Romanello C, Bouissou F, Gervaix A, Gurgoze MK, Bressan S, Smolkin V, Tuerlinckx D, Stefanidis CJ, Vsos G, Leblond P, Gungor F, Gendrel D, Chalumeau M: Association of procalcitonin with acute pyelonephritis and renal scars in pediatric UTI. Pediatrics 2013, 131(5):870-9.

29. Tuerlinckx D, Vander Borght T, Glupczynski Y, Galanti L, Roelants V, Krug B, de Bilderling $G$, Bodart E: Is procalcitonin a good marker of renal lesion in febrile urinary tract infection? Eur J Pediatr 2005, 164(10):651-652.

doi:10.1186/1471-2490-14-45

Cite this article as: Xu et al.: Procalcitonin and C-reactive protein in urinary tract infection diagnosis. BMC Urology 2014 14:45.

\section{Submit your next manuscript to BioMed Central and take full advantage of:}

- Convenient online submission

- Thorough peer review

- No space constraints or color figure charges

- Immediate publication on acceptance

- Inclusion in PubMed, CAS, Scopus and Google Scholar

- Research which is freely available for redistribution

Submit your manuscript at www.biomedcentral.com/submit 